\title{
Museientreprenörskap som praktik- och kunskapsfält
}

\author{
ANDERs Högberg \& MARINa Jogmark
}

\begin{abstract}
This study, "Museum entrepreneurship as practice and knowledge field", examines how museum directors view museum entrepreneurship, why they think it is important and how it can develop. Results show that the museum directors view entrepreneurship from a broad perspective that goes beyond a traditional image of entrepreneurship as exclusively an economic phenomenon. The results emphasize the need to turn to museum entrepreneurship as a way of thinking about renewal of museum activities, solving financial problems linked to decrees in public funding, find new sources of income and to create business models that have potential to refine opportunities coming from digitalization. The need for museum entrepreneurship is also about clarifying an awareness of what kind of values are created and how these can be formed while maintaining integrity in collaboration with the rest of society. The results also show that there is a need to develop museum entrepreneurship through collaborative research approaches.
\end{abstract}

Keywords: Social Entrepreneurship, Museum Studies, New Museum Ethics, Interview Study, Museum Directors.

Om marknadsavdelningen tillåts styra, då går det åt skogen, citat från en av de intervjuade museiledarna.

Museer samlar, vårdar och tillgängliggör samlingar och arkiv. De skapar utställningar, utbildningsprogram och andra former av publika aktiviteter. De är rådgivande kunskapsinstanser, exempelvis i frågor om stadsplanering och kulturmiljövård. Museerna är också sociala institutioner. De öppnar upp för diskussion, inspiration och eftertanke genom en mångfald av aktiviteter och evenemang. De förser samhället med sociala arenor för samtal, kun- skapsutveckling och erfarenhetsutbyte. Som del av besöksnäringen lockar museerna miljontals människor varje år. De erbjuder unika upplevelser, nöjen och äventyr och bidrar till kunskaper och erfarenheter som inte andra aktörer gör. Allt detta gör museerna i en samhällskontext där deras verksamheter allmänt ses som "en medborgerlig rättighet i likhet med tillgång till god utbildning och hälsovård" (Blomgren \& Johannisson 2015:10) och där förståelsen av museernas strukturella och marknadsmässiga karaktär som ett eget affärsmässigt och ekonomiskt avsättningsområde är 
underutvecklad och den museientreprenöriella kunskapen generellt är låg (Lundberg 2002; Coman \& Pop 2015; Booth \& Powell 2016; Katsoni \& Stratigea 2016; Sacco 2016; Gould \& Pyburn 2017; Gradén \& O’Dell 2017).

Entreprenörskap kan förstås på olika sätt. Vanligt är att uppfatta entreprenöriell skicklighet som förmågor att förstå ekonomins roll i samhället, göra lämpliga ekonomiska val, utveckla nya affärsmöjligheter samt öka produktivitet och lönsamhet. Sätt att göra detta på är att vara kreativ, innovativ och utveckla nya sätt att verka med förmågan att kombinera saker på nya sätt (Lindkvist 2015). Detta är en föreställning om entreprenörskap som ett skapande av något nytt som ännu inte finns (Shane 2003). Det handlar således om en kreativ organisering av människor och resurser. Som Höglund och Mårtensson (2019:14) diskuterar riskerar emellertid en okritisk applicering av mainstream "entrepreneurial attitudes, behaviours and capabilities [...] in the public sector [...] hampering basic ideals such as accountability, equal treatment and democratic values" (se också Berglund et al. 2021 för kritisk diskussion samt Gradén \& O'Dell 2020 för liknande diskussion i relation till museer). I ljuset av sådan kritik fokuserar socialt entreprenörskap på att pröva, analysera och konstruktivt utveckla sambanden mellan entreprenörskap och sociala relationer (Dees 1998a; Roper \& Cheney 2005; Barinaga 2012). Socialt entreprenörskap placerar entreprenörskapets kreativa skickligheter i samhället. För att använda Hjorths (2013:37) ord så handlar det om att "intensify the social side of entrepreneurship and see this as a creative intervention that increases the social capacity of society, rather than extending the performance capacity of management". I praktiken kanaliseras socialt entreprenörskap till innovativt arbete som medverkar till social förändring.
Entreprenörskap på museer och museer 75 som entreprenörer har diskuterats i flera sammanhang. Exempelvis har aspekter av att skapa hållbarhet i museisektorn genom att attrahera sponsorer eller filantroper till att investera $\mathrm{i}$ museets verksamheter, förutsättningar för museer att vara sociala eller kulturella innovatörer i sin realisering av museets existerade värden eller konsekvenser av att skapa kommersiellt utvecklade entreprenöriella museer undersökts (Alexander 1999, 2020; Rentschler 2001; Steyaert \& Katz 2004; Wilson 2010; Klamer 2011; Coman \& Pop 2015; Zaman 2015; Katsoni \& Stratigea 2016; Gradén \& O 'Dell 2017, 2020; Riksutställningar 2017; Ekström 2020). Begreppet museientreprenörskap tar detta vidare genom fokus på kunskaper och förmågor som behövs för att i samverkan uppfinna och utveckla framtida museiverksamheter (för alternativ användning av begreppet museientreprenörskap, se exempelvis Gradén \& O'Dell 2020). Museimedarbetarrollen präglas av komplexitet, mångtydighet och motsägelsefullhet i ett uppdrag under ständig förändring. Museipersonalens etiska position innebär att värna verksamheten utifrån den specifika kompetens man har och med hänsyn till samhällets förväntningar och regleringar. För museianställda på Sveriges museer är detta en viktig utgångspunkt för arbetet och en avgörande professionsskicklighet för museers trovärdighet, förmåga och framgång (Lindqvist 2019a). I begreppet museientreprenörskap kombineras museimedarbetarnas många roller med socialt entreprenörskap, ett entreprenörskap som då inte låter sig begränsas till att enbart vara ett ekonomiskt fenomen (se Lundberg 2002 för diskussion), utan även inkluderar museets sociala liv med förståelsen för entreprenörskap som en kollektiv social process. Detta är perspektiv som ligger i linje med hur Marstine (2011:10) formulerat sig om den nya 
museietiken där relationen mellan museet och det omgivande samhället är i fokus: " [...] the new museum ethics positions contributions to social well-being, equity and fairness as an integral part of museum work".

I denna studie undersöker vi hur ett urval av museiledare verksamma i Sverige tänker om museientreprenörskap, varför de anser att det är viktigt och hur de ser att museientreprenörskap kan utvecklas. Studien är inte en kritisk analys (sådana har andra publicerat, se exempelvis Berglund et al. 2017 för kritik av entreprenörskapets kopplingar till neo-liberalism och Schubert 2016 för kritik av instrumentella och ekonomiserade museer som marknadsplatser). Istället knyter studien an till forskning som undersöker museientreprenöriella villkor för att förvalta och utveckla museerna och deras verksamheter i samverkan med samhället (se diskussion i Alexander 2020).

\section{EN SEMI-STRUKTURERAD INTERVJUSTUDIE}

Studien baseras på semi-strukturerade kvalitativa intervjuer. Samma fem frågor, tabell 1, ställdes till samtliga medverkande, samtidigt som intervjusamtalet genomfördes med låg grad av standardisering med utrymme för uppföljningsfrågor och spontana diskussioner (Gillham 2008; Kvale \& Brinkmann 2014).

Samtliga museiledare är erfarna i sin yrkesroll. De ingår sedan några år tillbaka i ett nätverk för samtal om museientreprenörskap och är därmed insatta i studiens problem- och kunskapsområden. Alla arbetar på museum som ägs av bolag, förening eller stiftelse. Merparten av dessa har, i jämförelse med andra museer med statliga eller regionala anslag, en hög grad av egenfinansiering. Museerna är Blekinge museum, Gotlands museum, Jamtli Östersund, Kalmar läns museum, Kulturen i

\begin{tabular}{|l|l|}
\hline 1. & $\begin{array}{l}\text { Vilken typ av museientreprenöriell } \\
\text { kunskap ser du att ditt museum behöver? } \\
\text { Varför? }\end{array}$ \\
\hline 2. & $\begin{array}{l}\text { Ser du att detta behov gäller specifikt ditt } \\
\text { museum eller skulle du beskriva det som } \\
\text { ett mer generellt behov i branschen? }\end{array}$ \\
\hline 3. & $\begin{array}{l}\text { Hur skulle du beskriva ett bra sätt för ert } \\
\text { museum att skaffa sig museientreprenöriell } \\
\text { kunskap? }\end{array}$ \\
\hline 4. & $\begin{array}{l}\text { Om du fick vara visionär och tänka } \\
\text { helt fritt utanför budget och nuvarande } \\
\text { strukturer, vilka nya museiverksamheter } \\
\text { ser du att museientreprenörskap kan skapa } \\
\text { som inte finns i nuläget? }\end{array}$ \\
\hline 5. & $\begin{array}{l}\text { Har din uppfattning om behovet av } \\
\text { museientreprenöriell kunskap ändrats } \\
\text { under detta ovanliga pandemiår? I så fall, } \\
\text { hur? }\end{array}$ \\
\hline
\end{tabular}

Tabell 1. Frågor som användes som utgångspunkt för samtal vid de semi-strukturerade intervjuerna med elva museiledare verksamma i Sverige. Intervjuerna genomfördes digitalt med Zoom under september och oktober 2020. Respektive intervju varade mellan 30 och 60 minuter och dokumenterades med anteckningar.

Lund, Nordiska museet, Nääs Slott, Prins Eugens Waldemarsudde, Regionmuseet Kristianstad och Stiftelsen Skansen. En av de intervjuade är nyligen pensionerad museichef och numera direktör för European Museum Academy. Studien bygger således på intervjusvar med utgångspunkt i ledarskapsperspektiv (för medarbetarperspektiv se exempelvis Dahlquist 2019), från personer med specifika kunskaper inom studieområdet (Trost 2010).

Intervjusvaren har analyserats och temati- 
serats i syfte att lyfta fram övergripande trender. Detta har gjorts genom att samla svar som rör liknande tankar inom temaområden (se Öhlander 2011). Dessa har kontextualiserats i relation till aktuella museidiskussioner och tidigare forskning. Nedan presenteras dessa temaområden under åtta rubriker: offentliga anslag minskar, behov av andra intäktskällor ökar; samspel mellan kunskapsfält behövs; verksamhetsutveckling och innovationer; utvecklade säljtjänster och fler affärsområden; digitalisering; museernas behov av forskning och forskningsbaserad kunskap; att $f_{a}^{\circ}$ in museientreprenöriell kunskap i organisationen; året 2020. Tillsammans tydliggör dessa teman museientreprenörskap som praktik- och kunskapsfält och de behov, möjligheter och begränsningar som museiledarna ser i ett utvecklat museientreprenöriellt arbete. Notera att resultaten, så som de presenteras, inte nödvändigtvis representerar gemensamma inställningar hos alla de som intervjuats. Notera också att även om vi intervjuat erfarna museiledare med kunskaper som sträcker sig utanför deras respektive museum, avser vi här inte att generalisera våra resultat till att gälla alla Sveriges museer.

\section{OFFENTLIGA ANSLAG MINSKAR, BEHOV AV ANDRA INTÄKTSKÄLLOR ÖKAR}

Sedan många år tillbaka har museernas årliga anslag inte skrivits upp i samma takt som kostnaderna ökat. Konkret har detta inneburit en gradvis minskning av medel för verksamheterna, successiva personalnedskärningar och alltmer pressade organisationer. Detta samtidigt som museerna utvecklar nya verksamheter, samhället tillskriver museerna allt fler uppgifter och större roller i relation till samhällspolitiska utvecklingsfrågor och antalet besökare på museerna och deltagare i museernas verksamheter ökar (Museer 2019; Museilag 2017:563;
RAÄ 2019; Gustafsdotter 2020; Sveriges Mu77 seers 2020). Detta är trender som hållit i sig under många år och som inte visar tecken på att förändras. Därmed är det realistiskt att se dessa trender som givna förutsättning för museerna (se diskussion i Gradén \& O'Dell 2017; Lindqvist 2019a).

Museiledarna är tydliga med att konsekvenserna av detta är flera. Om museerna enbart förlitar sig på anslagsmedel, blir verksamheterna kvantitativt och kvalitativt lidande. Det riskerar att göra museerna mindre angelägna och bidrar till att potentialer som finns i museernas verksamheter inte realiseras. Det finns inte heller tillgångar för att finansiera förändringsidéer som går utanför anslagsbudgetens begränsningar. Inte heller finns möjligheter till riskkapital eller att fondera medel för framtida strategiska satsningar eller att investera i något nytt som inte ger direkt avkastning.

Merparten av museiledarna poängterar nödvändigheten i att förändra dessa förutsättningar genom att öka de delar av intäktssidan som inte kommer från anslag (se också Gradén \& O'Dell 2017). Ökade intäkter möjliggör utveckling av museiverksamheterna. Genom andra intäkter än de anslagsberoende kan museerna investera i verksamhetsutveckling. De kan frigöra utrymme att jobba mot kvalitativa visioner i relation till museernas uppdrag och mål. På så sätt kan museientreprenöriell kunskap ge kunskapsförankrade och mer innehållsrika museiverksamheter. En mångfald av intäkter gör också museerna mindre sårbara, då riskerna för intäktsbortfall fördelas över flera områden.

\section{SAMSPEL MELLAN KUNSKAPSFÄLT BEHÖVS}

Flera av museiledarna berättade om svårigheter att introducera museientreprenöriell kun- 
skap på sina arbetsplatser. Det finns en skepsis från delar av personalen som anser att museientreprenörskap inte ska finnas på museerna. Det finns flera orsaker till detta (Gainon-Court \& Vuillaume 2016). En är att museientreprenörskap möter kritiskt tvivel från akademin (se diskussion i Ekström 2020) och fram tills nyligen inte ingick som del av museianställdas utbildning (Lindqvist 2019b). Inte heller ingår museientreprenörskap som kompetens i kravprofiler för anställning. Det saknas alltså förutsättningar för en gemensam museientreprenöriell kunskapstradition inom museerna att tänka och agera utifrån. En annan väsentlig orsak är att museernas verksamheter under lång tid influerats av 1974 år kulturpolitiska formulering "att motverka kommersialismens negativa verkningar inom kulturområdet". En konsekvens av detta är att kunskaper om hur museerna kan generera positiva aspekter av entreprenörskap inte utvecklats i någon större utsträckning (Grinell \& Högberg, 2020). Detta har ändrats på senare år. Med förändringar i universitetsutbildningarna (Lindqvist 2019b), nya svenska kulturpolitiska mål (prop. 1996/97), en ny kulturarvspolitik (prop. 2016/17:116), en ny svensk museilag (Museilag 2017:563), samt internationella organisationer som exempelvis OECD:s engagemang i dessa frågor (Grinell 2020), har museientreprenörskap uppmärksammats (se diskussion i Gradén \& O'Dell 2017; Lindqvist 2019a).

Kritiken mot museientreprenörskap grundas ofta i en strävan att slå vakt om vad som uppfattas som museets kärna och identitet. Samtliga museiledare poängterar också att det är helt avgörande att inte förlora fokus på det unika i museets verksamheter. Kringbyggnaden - det vill säga den mångfald av aktiviteter som skapar breda intäktsbaser - får inte bli så brokig att museet förlorar identitet och riktning. De intervjuade är tydliga i detta. Det råder konsensus om att anledningen till att museer är viktiga och starka aktörer i samhället är att de är unika i sina verksamheter som just museer. Därför är det helt avgörande att inte kompromissa med detta. Museerna ska utgå ifrån sina unika verksamheter och identitet och inte förlora sig i verksamheter som vem som helst kan göra eller som andra (sannolikt) redan gör bättre (se liknande diskussion i Dees 1998b; Roper \& Cheney 2005; Lundberg et al. 2016). Om de tillgångar museet har $\mathrm{i}$ form av sina unika verksamheter på något sätt skulle komprometteras (se exempelvis Andersson 2017), så förlorar museet trovärdighet (se Salle 2014; von Unge 2019 för diskussion).

De intervjuade lyfter fram att det är nödvändigt att koppla museientreprenörskap till samhällsfrågor och museets samhällsuppdrag, så som det formulerats i regionala och nationella riktlinjer och lagar. Här kan museientreprenörskap handla om att hitta och skapa möjligheter till nya sammanhang att verka inom. Det handlar om att åstadkomma innovationer och företagsamhet som bidrar till ekonomiskt, socialt och kulturellt värdeskapande, förändring och framsteg och som kan förvaltas av museerna som en självklar del av verksamheterna och som därmed får dessa att växa utanför befintliga ramar. Att ha kunskap och kompetens i organisationen om hur detta bäst kan göras är avgörande för framgång.

I relation till detta var det flera av museiledarna som betonade att det behövs kunskap om hur museet kan agera både som en offentlig kulturinstitution och som en kulturkonsult på en marknad. Vad många pratade om som "ett gränssnitt" mellan museal kunskap, museologi och entreprenöriell kunskap lyftes och frågan om hur ett sådant gränssnitt ser ut och vilken kunskap som behövs för att formulera det ses som väsentligt att undersöka. Nationell och internationell forskning visar att museer har 
hög trovärdighet. Medborgare och samhällsinstitutioner har höga förväntningar på museerna som kunskapsinstitutioner, besöksmål och som viktiga samhällsfunktioner som bidrar till innovation och utveckling (Rogan \& Amundsen 2010; Coombes \& Philliphs 2015; Henning 2015; McCarthy 2015; Message \& Witcomb 2015; Hyltén-Cavallius \& Svanberg 2016; Lund 2016). Det krävs därmed kunskap och känsla för att balansera de många förväntningar, åtaganden och möjligheter en museiverksamhet rymmer så att museientreprenörskap utvecklas utan att det sker på bekostnad av etablerad goodwill, och om det sker på bekostnad av etablerad goodwill att det då är resultat av genomtänkta strategier och inte konsekvenser av oförutsedda effekter (Alexander 1999). Som diskuterats av Gradén och O'Dell (2017) krävs kunskapsbaserade överväganden för att upprätthålla balansen mellan att tillhandahålla samhällsservice och samtidigt själv vara en kommersiell aktör (se också Zolberg 1986; Alexander 2020). Detta är svårt. Flera av de intervjuade museiledarna vittnar om att de själva och museipersonalen upplever att de ibland sitter på två stolar samtidig. Förväntningarna på museet är att det ska tillhandahålla tjänster inom ramarna för anslagsfinansieringen. Samtidigt är det så att museerna gör mycket mer än det. Konflikten som finns i detta märks också i möten med människor och organisationer utanför museet. Många förstår inte museet som en affärsverksamhet och har svårt att skilja på museet som allmän kulturinstitution och museet som konsult med specialistkompetens. Gränsen mellan anslagsverksamhet och annat som man tar betalt för är oklar och därmed svår att hitta. Att hitta sätt att skapa kopplingar mellan museiverksamheter och entreprenörskap på ett sätt så integritet och förtroende upprätthålls samtidigt som nya verksamheter som genererar intäkter och ökat genomslag i samhället kan utvecklas är en viktig fråga för 79 många av museiledarna. Att ha kompetens att förstå och hantera detta "gränssnitt" kräver kunskap om vilka delar av verksamheten som kan generera vinst, och vilka som inte gör det. Det är kompetens som kan tydliggöra vad som är fritt tillgängligt genom anslagsverksamheten och vad som inte hade funnits tillgängligt (alltså inte erbjudits) om museet inte tagit betalt för det. Att närma sig detta sektors-överskridande arbete med olika verksamhetslogiker kräver ny kunskap som, vilket flera av museiledarna betonade, museerna till stora delar saknar i nuläget.

\section{VERKSAMHETSUTVECKLING OCH INNOVATIONER}

Museiledarna är eniga i att museientreprenöriella kunskaper och kompetenser på museerna öppnar upp för verksamhetsutveckling och innovationer. Mångfalden i detta är stor. Det handlar exempelvis om fördjupad forskningskunskap som kan utgöra grund för utställningsarbete. Detta skulle kunna öka genomslagskraften i verksamheterna, bidra till att museerna substantiellt och strategiskt kan jobba mot interna och externa mål- och visionsdokument samt locka fler besökare till museet och dess verksamheter. Det handlar också om utveckling av utåtriktade verksamheter, pedagogiskt arbete och arbete inom kulturmiljöområdet där innovativt tänkande skulle kunna öppna upp för nya verksamheter som når målgrupper museerna inte når idag.

Ett område som museiledarna lyfter fram är behovet av museientreprenöriell kunskap för att kvalitativt utveckla museernas samverkansarbete med besöksnäringen. Genom sin nationella och internationella attraktionskraft spelar Sveriges museer en avgörande roll i utveckling av svensk turism och besöksnäring. 
En utredning presenterad 2017 (Ett land att besöka 2017) visar på vikten av att stärka svensk besöksnäring som exportmarknad. Enligt utredningen uppskattades turismkonsumtionen i Sverige ha omsatt uppemot 300 miljarder kronor. Cirka 170000 personer var sysselsatta. Värdet av inhemska besökares konsumtion uppgick till cirka 60 procent av den totala konsumtionen. De resterande 40 procentenheterna kom från utländska besökare. Detta skapade ett exportvärde på 120 miljarder kronor, vilket då motsvarade ungefär 6 procent av Sveriges totala export. Museerna är en viktig och naturlig del i utvecklingsstrategier för turism och besöksnäring. I destinationsutvecklingen föds nya marknader. En sammanhållen marknadstillväxt ger ökad företagsamhet, konkurrenskraft och sysselsättning i samhället i stort och bidrar till exempelvis stärkt lokal attraktionskraft, livskraftiga stadskärnor och landsbygdsutveckling (see diskussion i Strzelecka et al. 2017).

Besöksnäringens utveckling innebär en ekonomisk tillväxt för museerna, men denna är ojämnt fördelad. Detta beror på skillnader i museernas förmåga att affärsmässigt utnyttja sin tillväxtpotential (se diskussion i Booth \& Powell 2016). Här poängterade flera av de intervjuade att det är viktigt att hitta produkter och verksamheter som särskiljer museerna från andra aktörer (andra besöksmål, andra butiker, andra arrangörer, etcetera) och som bygger på, lyfter fram och stärker det unika i museets verksamheter. I detta sammanhang lyftes också det faktum fram, att många externa företag använder museet som del av deras besöksaktiviteter utan att intäkterna från dessa aktiviteter kommer museet till godo. Inom besöksnäringen är det exempelvis vanligt att använda museibesök som del av ett upplevelsepaket, utan att företaget som gör det återinvesterar i museet. Detta kan ändras genom att skapa företagsrelationer som innefattar att museet växer och utvecklas tillsammans med näringsverksamheten. Dock lyfter flera fram att det i sådana sammanhang saknas tillräcklig kunskap om värdet i museet och dess verksamheter som del av besöksnäringen.

\section{UTVECKLADE SÄLJTJÄNSTER OCH FLER AFFÄRSOMRÅDEN}

Falk och Dierking (2011) har undersökt konsumtion som en integrerad del av upplevelser på museer. Exempelvis så visar de att besökare tenderar att spendera mer tid i museibutiken och museirestaurangen än vad de gör i utställningen. Museientreprenörskap handlar i detta sammanhang om att utveckla säljtjänster inom café, restaurang och butik (Theobald 2000). Flera informanter lyfter fram att det är viktigt att hitta personal med kunskap och kompetens som förstår hur dessa verksamheter kan drivas på sätt som gör dem till en integrerad del av upplevelsen av att besöka museet, samtidigt som dessa verksamheter genererar intäkter (se Alexander 2020 för diskussion).

Många uttryckte behov av museientreprenöriell kunskap som kan skapa verksamhetsprocesser som tar en god idé till fullgod affär. En av museiledarna formulerade det så här: "Goda idéer finns det gott om i vår verksamhet, men kunskap om hur dessa idéer organisatoriskt kan omsättas i faktiska processer som leder till något det går att göra affärer av finns inte. Sådan kunskap behöver vi”. Det kan röra sig om att utveckla arrangemang och eventsidan av museiverksamheten eller skapa aktiviteter att ta betalt för som lockar nya målgrupper till museibesök eller som ger mervärde för den vane museibesökaren. Detta är ett fokus på museientreprenörskap som något som kan utveckla såväl museernas verksamheter, som deras sätt att öka museernas intäkter genom 
att tydliggöra exploateringsprocessen av en affärsmöjlighet.

\section{Digitalisering}

De senaste åren har det pumpats in mångmiljonbelopp i arbetet med digitalisering av kulturarvet, inte minst genom riktade utlysningar koordinerade av stora forskningsfinansiärer (prop. 2016/17:50:94f; Joelsson 2020). Frågor om digitalisering har således stor inverkan på museerna (Winesmith \& Anderson 2020).

Digitalisering togs också upp av museiledarna som en viktig del av museientreprenöriella satsningar. Flera poängterade att museerna saknar affärsmodeller för digitalisering. I nuläget driver museer utveckling av verksamheterna utifrån egna resurser. Det resulterar i att många uppfinner hjulet samtidigt. En större nationell samordning skulle underlätta för enskilda museer att utveckla affärsmodeller för att dra fördel av den ökade digitaliseringen. Rasmussen (2019) visar att förändrade institutionella praktiker har inflytande över hur framgångsrika museer är i sitt digitaliseringsarbete. Booth med kolleger (2019) lyfter fram museichefers kunskaper och kompetens som viktigt för museets digitala utveckling. I relation till detta lyfte flera av de intervjuade fram behovet av nytänkande och innovativa nationella inkubatorverksamheter för branschen som ett sätt att utveckla museernas verksamheter. Som en av de intervjuade uttryckte det: "Det borde vara en framgångsfaktor att jobba tillsammans i Sverige med dessa frågor, ett nationellt perspektiv behövs".

Flera tydliggjorde att det behövs driftkompetens inom digital produktion. Museerna är många gånger framgångsrika i att ta fram digitalt tillgängliga produkter men har begränsade kunskaper om den digitala marknaden för produkten. Därmed når produkten få, och många gånger de redan insatta. Museientreprenöriellt upp museernas digitala kompetenser och också skapa nya marknader baserat på museernas möjligheter att forma unika autentiska digitala upplevelser. Detta genom en museiförankrad kunskap om potentialerna i det kommersiella digitala landskapet. Museientreprenörskap handlar då om förmågan att översätta symboliska värden till finansiella för att möjliggöra en fortsatt autentisk kulturproduktion.

\section{MUSEERNAS BEHOV AV FORSKNING OCH FORSKNINGSBASERAD KUNSKAP}

Museientreprenörskap som förmågan att tänka nytt, innovativt och konstruktivt kopplas också till behov av forskning och forskningsbaserad kunskap och kompetens förankrad i museernas förutsättningar och verksamheter. Ett museientreprenöriellt perspektiv handlar i detta sammanhang om att kunna anställa in forskare som är entreprenöriella i sitt förhållningssätt och som genom sin forskning bidrar till att utveckla museets visioner, konkret stärker museets strategiska inriktning och kan leverera forskning som kan utveckla museet och dess verksamheter (se Bäckström 2016). I detta sammanhang knyts alltså museientreprenörskap till kunskaper och egenskaper som behövs för att utveckla befintliga verksamheter kopplade till museets förvaltning, samlingar och publika aktiviteter, inte till affärstänk, besöksnäringen eller nya marknader. Museientreprenörskap blir i detta ett redskap för att förverkliga museet så som det tar sig uttryck i målformuleringar, visioner och strategidokument. För att verkliggöra detta krävs tillgång till forskare som kan axla en sådan museientreprenöriell roll. Till delar är detta en annan form av forskning än den som universiteten levererar (Bäckström 2016; Bygdell \& Hansen 
2019). Av intervjuerna framkom att det i nuläget är svårt för museerna att rekrytera forskare med den förmåga och kunskap som behövs. Museet behöver museiforskare som har förmågan att forska om relevanta frågor i en museikontext, något få forskare är utbildade för. Det kräver också rätt beställarkompetens i museets ledning, det vill säga en förmåga att förstå vad museet behöver. Det behövs också en organisation som kan hantera och omsätta den kunskap som kommer ur forskningen i relevant museiverksamhet. Detta är resultat som ligger i linje med tidigare studier (Bygdell \& Hansen 2019) och som knyter an till hur museer och forskare förstår samverkansforskning.

Integrerad strukturerad samverkansforskning handlar konkret om att utveckla arbetssätt och resultat i samspel med praktisk verksamhet genom att forskningsanknyta praktiken och praktikanknyta forskningen. Framgångsrikt genomfört resulterar sådan samverkansforskning i robust kontextkänslig kunskap vars validitet prövats i dialog. Det ökar deltagarnas kunskaper och kompetenser och ger verksamhetsförankrad kunskap av hög vetenskaplig kvalitet (Holmquist 2018).

Flera har visat att vinsten med sådan samverkan är att resultat skapas som inte någon av deltagarna själv skulle kunna generera (Perez Vico 2018; Lindqvist 2019c). Detta är väsentligt. Olika former av samverkan leder till ny kunskap som kommer ur själva samverkan (fig. 1). Vad färre har lyft fram är samverkan som har som mål att få samverkanspartners att skapa inte bara ny kunskap utifrån befintliga resurser, utan också skapa insikt om nya kunskaps- och utvecklingsområden (se Holmquist 2018 för diskussion). Med detta menas samverkan som redan $i$ initieringsfasen hittar nya kunskapsområden som ingen av de inblandade tänkte sig existerade eller kunde tänka sig att de behövde, men som när de väl verbaliserats visar sig vara väsentliga för verksamheternas framgång (Miller 2011).

Figur 1 illustrerar ett antal exempel som spänner över arbetsinsatser som inte inkluderar någon samverkan alls, till de som är nyskapande samverkan. Resultaten av vår studie visar att samtidigt som exempel ett, två och tre i figuren är vanligt i museisverige (Otto \& Villstrand 2008), är det inte det museiledarna främst efterfrågar. Istället är det samverkansforskning som exempel fyra och fem i figur 1 som museerna uttrycker behov av. Exempel sex i figuren är inget som museerna har formulerat men är något som, menar vi, har ytterligare potential att utveckla ny förståelse av forskningssamverkan som museientreprenöriell praktik.

\section{ATT FÅ IN MUSEIENTREPRENÖRIELL KUNSKAP I ORGANISATIONEN}

Lindqvist (2019a) har publicerat en genomlysning av vilka kompetensförsörjningsbehov som museer i Sverige står inför. Utgångspunkten i hennes studie är att museer idag möter en värld i förändring som ställer krav på museiverksamheterna och anställda att utveckla kompentenser bortom vad som fram tills nyligen sågs som tillräckligt (Lindqvist 2019a). Detta ligger väl i linje med hur de som intervjuats i vår studie uttrycker sig om vikten av att få in museientreprenörskap i sina organisationer och de svårigheter som de ser är förknippade med detta.

Flera av museiledarna poängterade universitetsutbildningens utformning och innehåll som viktig. Museerna behöver kunna rekrytera nyexaminerade personer som förstår museientreprenörskap och som fått en utbildning som ger dem förutsättningar att arbeta i det "gränssnitt" mellan museal kunskap, museologi och entreprenöriell kunskap som diskuteras ovan. 


\begin{tabular}{|c|c|c|}
\hline 1 & $\begin{array}{l}\mathbf{F} \\
\mathrm{U}\end{array}$ & $\begin{array}{l}\text { Forskare lokaliserad utanför museet forskar om museet. Det } \\
\text { görs utifrån forskarens val av frågeställning, metod, teori och } \\
\text { empiriskt material. Resultatet presenteras i forum valt av } \\
\text { forskare. }\end{array}$ \\
\hline 2 & $\mathbf{F}$ & $\begin{array}{l}\text { Forskare lokaliserade på museet forskar om museet eller på } \\
\text { museets samlingar eller verksamheter. Det görs utifrån } \\
\text { forskarens val av frågeställning, metod, teori och empiriskt } \\
\text { material. Resultatet presenteras i forum tillgängligt för museet. } \\
\text { Detta och exemplet ovan är inte samverkan. }\end{array}$ \\
\hline 3 & $F-$ & $\begin{array}{l}\text { Museet beställer forskning om något som museet behöver } \\
\text { kunskap om. Forskaren levererar resultatet när uppgiften är klar. } \\
\text { Eftersom det ofta gått långt tid mellan beställning och leverans, } \\
\text { är det vanligt att det museet behövde kunskap om (vid } \\
\text { beställningen), inte längre är helt relevant (vid leveransen). } \\
\text { Detta eftersom museets verksamheter, forskningsfronten och } \\
\text { omvärlden hunnit förändras under processen. }\end{array}$ \\
\hline 4 & M & $\begin{array}{l}\text { Museet beställer forskning om något som museet behöver } \\
\text { kunskap om. Genom hela processen återkopplar forskare till } \\
\text { museet och aspekter av forskningsfrågor, metoder, teorier och } \\
\text { empiriskt urval uppdateras kontinuerligt genom feedback från } \\
\text { museet och i takt med att forskningen gör framsteg. Detta gör att } \\
\text { beställningen bibehåller relevans. När resultatet levereras av } \\
\text { forskaren är det uppdaterat i relation till museets pågående } \\
\text { verksamheter, forskningsfronten och omvärldens behov och } \\
\text { önskemål. Detta och exemplet ovan är forskningssamarbeten } \\
\text { som ibland kallas tillämpad forskning (Jonsson Malm \& } \\
\text { Petersson 2019). }\end{array}$ \\
\hline 5 & M & $\begin{array}{l}\text { Samverkan präglar hela processen. Initialt kommer forskare och } \\
\text { museet överens om vad som är relevant att undersöka. Arbetet } \\
\text { sker både hos forskaren och på museet. Återkoppling och } \\
\text { avstämning dem emellan samt nyansering, uppdatering och } \\
\text { utveckling av forskningsfrågor, metoder, teori och empiriskt } \\
\text { material sker återkommande igenom hela processen. Resultatet } \\
\text { levereras av forskare och museet tillsammans. Denna form av } \\
\text { forskningssamverkan är vad Perez Vico (2018:31) definierar } \\
\text { som "en dubbelriktad interaktiv process [...] där man } \\
\text { tillhandahåller varandra nyttor som man annars har svårt att få } \\
\text { access till". }\end{array}$ \\
\hline 6 & & $\begin{array}{l}\text { Forskningssamverkan där initieringsfasen används för att skapa } \\
\text { något nytt i själva mötet mellan forskning och museipraktik. } \\
\text { Detta nya är något som endast kan uppstå i själva mötet. Det } \\
\text { resulterar i problemformuleringar, forskningsbehov eller } \\
\text { undersökningsfält som inte existerade innan mötet skedde. } \\
\text { Forskningssamverkan ger på så sätt något nytt som ingen av } \\
\text { samverkansparterna sedan tidigare visste att man behövde } \\
\text { forska om eller utveckla. När detta nya etablerats som ett } \\
\text { samverkansarbete, arbetar man sömlöst tillsammans igenom } \\
\text { hela processen mot ett gemensamt resultat. Denna form av } \\
\text { samverkan har kallats interaktiv kunskapssamverkan (Holmquist } \\
\text { 2018). }\end{array}$ \\
\hline
\end{tabular}

Fig. 1. Exempel på olika sätt att förstå samverkan och forskning på museer. F=forskare. $M=$ museum. Pilar visar rörelse i processerna. 
Samtliga intervjuade betonade att en stark utbildning i museiämnen och museologi är helt nödvändig, men att det till detta också behövs museientreprenöriell kompetens som kan utveckla museets framtida roll som samhällsaktör. Flera poängterade att det i detta sammanhang handlar om såväl individers kompetens och kunskap, som organisationens förmåga att se till att kompetensen sitter i organisationen och inte enbart hos enskilda individer. Att kunna rekrytera nyutbildade personer med kompetens att realisera detta ses som värdefullt. En iakttagelse är att detta ligger väl i linje med hur museibranschen tidigare uttryckt sig om sådana behov (se Lindqvist 2019d), samtidigt som det till stora delar står i kontrast till resultaten av en undersökning där fackförbundet DIK tog hjälp av sina medlemmar för att ringa in museernas framtida kompensbehov i vilken museientreprenörskap inte nämns (Dahlquist 2019). Huruvida denna diskrepans mellan resultat av olika undersökningar visar på faktiska skillnader mellan museichefers och museianställdas syn på vilken kunskap och kompetens framtida museer behöver, eller om skillnaderna kan härledas till variationer i utgångspunkter och frågeformulär i respektive undersökningar är en fråga för framtida forskning.

Några museiledare lyfte också fram behov av personalutveckling i form av kurser, fortbildning och stöd $\mathrm{i}$ verksamheten som långsiktigt kan ge en fördjupad medvetenhet om museientreprenörskap som en väsentlig kunskapsdel i museets verksamhet.

Flera museichefer betonade att nytänkande kompetens behövs för att förstå näringslivet. Generellt har museerna ofullständig kunskap om hur näringslivet fungerar. Detta innebär att sätten att bemöta och samverka med näringslivet riskerar att bli mindre konstruktiva än vad de potentiellt skulle kunna bli. Kon- kret betyder detta att museerna dels behöver kunskap om "affärslivet", dels kunskap för att förstå "museets egna affär" genom att kunna prata om den på ett sätt som är begripligt för de man möter. Flera av museiledarna menade att detta är viktiga delar av museientreprenöriell kunskap som museerna behöver få in i sina organisationer. Ett förslag som flera lyfte fram till hur detta kan åstadkommas är genom samverkan med andra sektorer. Genom att se till att museet medverkar i sammanhang där kunskapen finns, kan museipersonalen lära sig genom aktivt deltagande. Ett konkret exempel som lyftes fram var förmågor som behövs för att konstruktivt kunna deltaga i lokala företagsföreningar och vara del i exempelvis samtal om framtida utveckling av besöksnäringen och lokalsamhället. Sådana förmågor skulle ge kunskap i museets verksamheter om hur man kan prata om sitt värdeerbjudande med näringslivet. Med detta menade de en förmåga att i relation till samhällets behov och önskemål tydliggöra vad museiverksamheterna faktiskt gör och inte gör. Detta är kunskap som skapar trovärdighet i museets roll som samverkanspart.

Flera vittnar om hur svårt det är att få in museientreprenöriell kunskap och kompetens i organisationen genom rekrytering (se Lindqvist 2019d:78f). Antingen får man in personer som kan museet eller så får man in personer som kan affärsmodellering och näringsliv. När man tar in personer med näringslivskunskap så förstår de fullt ut områden som handlar om kundkrets och att maximera intäkter. Men, samtidigt förstår de inte det delikata $\mathrm{i}$ vad museet faktiskt är. Och från "kultursidan”, det vill säga de som är i verksamhetens kärna och har sin utbildning i museiämnen, förstår man inte det museientreprenöriella. Att rekrytera någon som behärskar båda dessa kunskaps- och kompetensfält är vad flera mu- 
seiledare vill, men inte alla fullt ut lyckats med (se också diskussioner ovan om "gränssnitt" mellan museal kunskap, museologi och entreprenöriell kunskap). Flera uttryckte att de behöver kunskap i organisationen som förstår hur affärsverksamheten relaterar till övrig museiverksamhet, så det ena inte blir lidande av det andra. I relation till detta poängterade flera att så kallad "säljkunskap" inte är det samma som "museikunskap som säljer". Det handlar alltså inte om att rekrytera in "sälj- och marknadsföringspersoner" som inte är förankrade i kunskap om det unika museet har att erbjuda. Vad museerna behöver är personer som förstår vad som fungerar och inte fungerar i relation till museiverksamheterna och som förstår hur intäkter från verksamheterna kan återinvesteras i museet. Som en av museiledarna uttryckte det: "Att få intäkter i affärsverksamheten, samtidigt som man förlorar trovärdighet i en annan del av museiverksamheten motverkar ju hela verksamhetens syfte". Att hitta personer med denna typ av dubbla kompetens nämns av många som en avgörande faktor för framgångsrik verksamhetsutveckling. Det är en kompetens som behövs i många delar av verksamheten och när den finns skapar "en trygg kultur" på arbetsplatsen där personalen bottnar i sina kunskaper och kan realisera saker enklare än nu.

Med utgångspunkt i en enkätundersökning från 2016 undersöker Lindqvist (2019d) hur länsmuseichefer bedömer sina museers befintliga kompetenser i relation till utvecklingsbehov som cheferna själva identifierar. Flera av de områden som Lindqvist identifierar ligger i linje med de som diskuterats här. Länsmuseerna berättar att de arbetar för att få in en större bredd av kunskap och kompetens i sina organisationer. Samtidigt är cheferna medvetna om att komplexiteten i kompetensen som efterfrågas gör det svårt att hitta personal som match- ar det man söker: "Denna önskvärda multikompetens hos ny personal omfattar både mer traditionellt museiinriktad kompetens och kompetens i kommunikation, digital teknik, språk, rättvise- och miljöfrågor och annat som är relevant för museet" (Lindqvist 2019d:78). Det är alltså tydligt att den nya kompetens som efterfrågas inte bara görs så från museer med hög grad av självfinansiering (som de som ingår i vår studie), utan ska ses som en generell efterfrågan i museisverige.

\section{ÅreT 2020}

Året 2020 var pandemins år. Påverkan på museibranschen var stor. Sveriges Museer har kalkylerat att svenska museer förlorat en halv miljard kronor under året (Gustafsdotter 2020). Året har visat museernas sårbarhet och utsatthet (Lundberg \& Hellberg 2020). Den stabilitet och kontinuitet som många har uppfattat som naturligt inbyggd i museerna har visat sig enkel att ifrågasätta när intäkterna uteblivit. Året har också tydliggjort en paradox. De museer som varit mest framgångsrika $\mathrm{i}$ att ta in externa medel och skapa intäkter utöver anslag, är de som drabbats hårdast av uteblivna besökare under året. De museer som sedan tidigare reducerat sina verksamheter i takt med minskade anslag har inte drabbats i lika hög grad. Detta har föranlett kritik av entreprenöriella museer (Hegardt 2020). Som merparten av museiledarena påpekade, så har dock museerna som reducerat sina verksamheter i takt med minskade anslag inte haft något större genomslag, varken tidigare eller nu.

Det som hänt, som en museiledare uttryckte det, "har lärt oss den hårda vägen att museerna behöver intäkter i verksamheten, efter detta året är det tydligt för alla”. Året har också väckt en större medvetenhet om museernas behov av att kunna planera långsiktigt, 
om att finna vägar till att skaffa sig en buffert för magra år.

Många av informanterna menar att året har visat hur viktigt museientreprenöriell kunskap är, då behovet av innovativt tänkande, mobilisering och förmåga till snabbhet och påhittighet blivit påtagligt. Året har tvingat museerna till att vara ännu mer kreativa. Det har tvingat museer att arbeta med frågan om "hur de kan bibehålla museets vision och verksamhet, samtidigt som de måste spara, skära, prioritera och utveckla nya sätt att få intäkter”, som en museiledare uttryckte det. Verksamheter har utvecklats för att balansera för utebliven publik. Några av dessa verksamheter kommer att bli permanenta inslag när pandemin är förbi.

Flera uttrycker en förhoppning om att året kanske medför att finansieringsfrågor kan börja diskuteras på nya sätt, att det ohållbara i nuvarande system blivit så tydligt att många nu tycker det är värt att diskutera alternativ.

\section{RESUltat}

I denna studie har vi undersökt museientreprenörskap som praktik- och kunskapsfält. Genom intervjuer med elva museiledare verksamma i Sverige har behov, möjligheter och begränsningar analyserats och svaren har kontextualiserats i relation till aktuella museidiskussioner och tidigare forskning. Svaren vittnar om en fördjupad insikt om museientreprenörskapets betydelser för museiverksamheterna, en insikt som sträcker sig förbi vad kritiker menar är nyliberalismens new public management-ekonomisering av verksamheterna (exempelvis Hegardt 2020), eller förenklade tankar om museerna som kuggar i kulturindustrins penninghjul (se Pyykkönen \& Stavrum 2018 för diskussion). Resultatet visar att museiledarna betonar ett museientreprenöriellt förhållningssätt som både ekonomiskt och socialt fenomen, som handlar om att mobilisera initiativ, vara innovativ och utveckla sätt att skapa värde i relation till museernas verksamheter och samhället de verkar i. Svaren uttrycker en efterfrågan på museientreprenörskap som kompetens och kunskap och framtida områden för forskning och utveckling pekas ut. Dessa handlar om kunskaper som behövs för att utveckla museientreprenörskapets roll som skapare av sociala, kulturella och ekonomiska värden och förnyare av samhälleliga institutioner. De handlar också om hur ett museientreprenöriellt arbete kan göras i samverkan med omgivande intressenter och hur museernas roll som fria tillgängliga resurser för samhället kan upprätthållas samtidigt som affärsverksamheter utvecklas, utan att kompromissa med samhällets förtroende för oberoende museiinstitutioner. Detta är aspekter av museientreprenörskapets möjligheter och begränsningar som vi avser att undersöka i framtida studier.

\section{ACKNOWLedgement}

Stort tack till alla museiledare som generöst bidragit med sin tid, kunskap och kompetens genom att medverka i intervjuerna. Tack också till Olov Amelin, Peter Aronsson, David Calås, Katarina Ellborg, Cornelius Holtorf, Lars Lindqvist och Henrik Zipzane för kommentarer till en tidigare version av texten, samt till två anonyma reviewläsare för konstruktiva kommentarer.

\section{REFERENSER}

Alexander, Victoria D 1999. "A delicate balance: Museums and the market place." Museums International 51:2, 29-34.

Alexander, Victoria D 2020. "Cultural policy effects on the marketing orientation in London art museums." I Karin M. Ekström (red). Museum Marketization. Cultural Institutions in the 
Neoliberal Era. London \& New York: Routledge, 81-97.

Andersson, Elisabet 2017. "Inget mutbrott i Nationalmuseums BMW-härva." Svenska dagbladet 2017-01-17. https://www.svd.se/ingetmutbrott-i-nationalmuseums-bmw-harva. Sidan besökt 5 april 2021.

Barinaga, Ester 2012. “Overcoming inertia: the social question in social entrepreneurship", I Daniel Hjorth (red.). Handbook on Organisational Entrepreneurship. Cheltenham \& Northampton, MA: Edward Elgar, 242-256.

Berglund, Karin, Anna Alexandersson, Marina Jogmark \& Malin Tillmar, 2021. "An Alternative Entrepreneurial University?” I Ulla Hytti (red.). A Research Agenda for the Entrepreneurial University. Cheltenham: Edward Elgar.

Berglund, Karin, Monica Lindgren \& Johann Packendorff 2017. "Responsibilising the next generation: Fostering the enterprising self through de-mobilising gender." Organization, 24(6), 892-915.

Blomgren, Roger \& Jennie Johannisson 2015.

"Kulturpolitik, styrning och legitimitet i svenska regionala kulturplaner." I Katja Lindqvist \& Anne Lorentzen (red.). Kultur för regional utveckling. Gränsløst. Tidskrift för studier av Öresundsregionens historia, kultur och samhällsliv. Nr 5, 9-19.

Booth, Peter. Anne Ogundipe \& Siri Røyseng 2019. Museum leaders' perspectives on social media. Museum Management and Curatorship, 35(4), 373-391.

Booth, Elizabeth \& Raymond Powell 2016. "Museums: Form Cabinets of Curiosity to Cultural Shopping Experiences.” I Vicky Katsoni \& Anastacia Stratigea (red.) Tourism and Culture in the Age of Innovation. Second International Conferenc IACuDiT, Athens 2015. Springer Proceedings in Business and Economics. London $\mathrm{m}$ fl. orter: Springer, 131-143.

Bygdell, Cecilia \& Anna Hansen 2019.
"Forskarutbildade - garanter för en forskande museisektor?" I Katja Lindqvist (red.). Kompetens i museisektorn. Politik, praktik och relationen till högre utbildning. Lund: Nordic Academic Press, 49-67.

Bäckström, Mattias 2016. Att bygga innehåll med utställningar. Utställningsproduktion som forskningsprocess. Lund: Nordic Academic Press.

Coman, Adela \& Izabela Pop 2015. "Entrepreneurship - the key for a successful museum." MPRA Paper No. 67430. https://mpra.ub.uni-muenchen. de/https://centers.fuqua.duke.edu/case/wpcontent/uploads/sites/7/2015/03/Article_Dees_ MeaningofSocialEntrepreneurship_2001.pdf. 67430/. Besökt 14 juni 2018.

Coombes, Annie E \& Ruth B Philliphs (red.) 2015. Museum Transformation. The International Handbooks of Museum Studies. Chichester: John Wiley \& Sons.

Dahlquist, Sofia 2019. "5D - en kompetenspolicy för framtidens museer." I Katja Lindqvist (red.). Kompetens i museisektorn. Politik, praktik och relationen till högre utbildning. Lund: Nordic Academic Press, 35-47.

Dees, J. Gregory 1998a/2001. "The meaning of social entrepreneurship." https://centers.fuqua.duke.edu/ case/wp-content/uploads/sites/7/2015/03/Article_ Dees_MeaningofSocialEntrepreneurship_2001. pdf. Besökt 28 oktober 2020.

Dees, J. Gregory 1998b. “Enterprising nonprofits.” Harvard Business Review, Vol. 76, JanuaryFebruary, 55-67.

Ekström, Karin M (red.) 2020. Museum Marketization. Cultural Institutions in the Neoliberal Era. London: Routledge. Ett land att besöka - En samlad politik för hållbar turism och växande besöksnäring. SOU 2017:95. https://www.regeringen.se/rattsliga-dokument/ statens-offentliga-utredningar/2017/12/sou201795/.

Falk, John H \& Lynn D Dierking 2011. The Museum Experience. London \& New York: Routledge. 
Gainon-Court, Marie-Agnès \& David Vuillaume 2016. "Can Museums Keep Up With a Changing World? Skills Management as a Practical Respons." Museum International No. 269-270, 81-96.

Gillham, Bill 2008. Forskningsintervjun: tekniker och genomförande. Lund: Studentlitteratur.

Gould, Peter G. \& Anne K. Pyburn (red.) 2017 Collision or Collaboration. Archaeology Encounters Economic Development. Cham: Springer.

Gradén, Lizette \& Tom O'Dell 2017. “Museum and heritage Collections in the Cultural Economy: The Challenge of Addressing Wider Audiences and Local Communities." Museum International, 68(3-4), 48-67.

Gradén, Lizette \& Tom O’Dell 2020. ”Hip Heritage and Hertiage Pasts. Tensions when re-fashioning museum culture." I Karin M. Ekström (red.). Museum Marketization. Cultural Institutions in the Neoliberal Era. London: Routledge, 115-133.

Grinell, Klas 2020. Kulturens värde och sociala effekter. Rapport 2020:1. Göteborgs stad: Kulturförvaltningen.

Grinell, Klas \& Anders Högberg, 2020. "Lagstadgad kunskap. Om svensk museipolitik och forskning." Nordisk Museologi 2020:2, 41-49.

Gustafsdotter, Jeanette 2020. Att positionera museisektorn är viktigare än någonsin. Utställningskritik, 2020(4), Reflektion. https:// utstallningskritik.se/2020-4/att-positioneramuseisektorn-ar-viktigare-an-nagonsin/. Besökt 17 december 2020.

Hegardt, Johan 2020. Skansen i tider av pandemier. Utställningskritik, 2020(4), Reflektion. https:// utstallningskritik.se/2020-4/skansen-i-tider-avpandemier/. Besökt 17 december 2020.

Henning, Michelle (red) 2015. Museum Media. The International Handbooks of Museum Studies. Chichester: John Wiley \& Sons.

Hjorth, Daniel 2013. "Public entrepreneurship: desiring social change, creating sociality." Entrepreneurship \& Regional Development, 25(12), 34-51.
Holmquist, Mats 2018. "Att utveckla en interaktiv samverkanskompetens." I Berg, Martin, Vaike Fors \& Robert Willim (red.). Samverkansformer. Nya vägar för humaniora och samhällsvetenskap. Lund: Studentlitteratur, 175-193.

Hyltén-Cavallius, Charlotte \& Fredrik Svanberg 2016. Älskade museum. Svenska kulturhistoriska museer som kulturskapare och samhällsbyggare. Lund: Nordic Academic Press.

Höglund, Linda \& Maria Mårtensson 2019. "Entrepreneurship as a Strategic Management tool for Renewal. The Case of the Swedish Public Employment Service." Administrative Sciences, 9(76). doi.org/10.3390/admsci9040076.

Joelsson, Eva 2020. Digitalt museimöte om digital omställning. Utställningskritik 2020(4), Rapport. https://utstallningskritik.se/2020-4/digitaltmuseimote-om-digital-omstallning/. Besökt 17 december 2020.

Jonsson Malm, Carolina \& Bodil Petersson 2019. ”Tillämpade, experimentella och forskningsanknutna arbetssätt i kulturarvsutbildningen." I Katja Lindqvist (red.). Kompetens i museisektorn. Politik, praktik och relationen till högre utbildning. Lund: Nordic Academic Press, 207-219.

Kunskap i samverkan - för samhällets utmaningar och stärkt konkurrenskraft. Prop. 2016/17:50. https:// www.regeringen.se/4adad0/ contentassets/72faaf7629a845af9b30fde1ef6b5067/kunskap-i-samverkan--for-samhallets-utmaningar-och-starkt-konkurrenskraft-prop.-20161750.pdf.

Katsoni, Vicky \& Anastacia Stratigea (red.) 2016. "Tourism and Culture in the Age of Innovation. Second International Conferenc IACuDiT, Athens 2015." Springer Proceedings in Business and Economics. London: Springer.

Klamer, Arjo 2011. "Cultural entrepreneurship." The Review of Austrian Economics, 24, 141-156.

Kulturarvspolitik. Prop. 2016/17:116. https://www.regeringen.se/4933fd/ 
contentassets/127b80d33b084194a415d-

72b85721874/161711600web.pdf

Kvale, Steinar \& Svend Brinkmann 2014. Den

kvalitativa forskningsintervjun. Lund:

Studentlitteratur.

Lindqvist, Katja (red.) 2019a. Kompetens $i$ museisektorn. Politik, praktik och relationen till högre utbildning. Lund: Nordic Academic Press.

Lindqvist, Katja 2019b. ”Högskoleutbildningar med museiinrktning i de nordiska länderna - mellan politik och praktik." I Katja Lindqvist (red.). Kompetens i museisektorn. Politik, praktik och relationen till högre utbildning. Lund: Nordic Academic Press, 269-301.

Lindqvist, Katja 2019c. "Samverkanskompetens." I Katja Lindqvist (red.). Kompetens i museisektorn. Politik, praktik och relationen till högre utbildning. Lund: Nordic Academic Press, 141-157.

Lindqvist, Katja 2019d. "Läns- och regionmuseers kompetens och utvecklingsbehov." I Katja Lindqvist (red.). Kompetens i museisektorn. Politik, praktik och relationen till högre utbildning. Lund: Nordic Academic Press, 69-80.

Lindkvist, Lars 2015. Vandalorum konst och designcentrum. "Kulturellt entreprenörskap och legitimerande ledarskap." I Katja Lindqvist \& Anne Lorentzen (red.). Kultur för regional utveckling. Gränsløst. Tidskrift för studier av Öresundsregionens historia, kultur och samhällsliv. Nr 5, 82-94

Lund, Johan 2016. Museet vid Korsvägen. Göteborg: Göteborgs universitet.

Lundberg, Hans 2002. "Historieberättande entreprenörer." I Peter Aronsson \& Erika Larsson (red.). Konsten att lära och viljan att uppleva. Historiebruk och upplevelsepedagogik vid Foteviken, Medeltidsveckan och Jamtli. Centrum för kulturvetenskaper: Växjö, 191-227.

Lundberg, Hans, Marcela Ramírez-Pasillas \& Anders Högberg 2016. "Towards a Conceptual Model for Heritagepreneurship and Regional Development." I Vicky Katsoni \& Anastacia Stratigea (red.).
Tourism and Culture in the Age of Innovation.

Second International Conference IACuDiT, Athens 2015. Springer Proceedings in Business and Economics. Switzerland: Springer, Cham, 23-44. DOI: 10.1007/978-3-319-27528-4_2.

Lundberg, Linda \& Jonas Hellberg 2020. En nationell kulturskuld I pandemins spar - effekter av corona i nutid och framtid. Utställningskritik, 2020(4), Reflektion. https://utstallningskritik.se/2020-4/ en-nationell-kulturskuld-i-pandemins-spareffekter-av-corona-i-nutid-och-framtid/. Besökt 17 december 2020.

Marstine, Janet 2011. "The contingent nature of the new museum ethics." I Janet Marstine (red.). The Routledge Companion to Museum Ethics. Redefining Ethics for the Twenty-First Century Museum. New York: Routledge, 3-25.

McCarthy, Conal (red.) 2015. Museum Practice. The International Handbooks of Museum Studies. Chichester: John Wiley \& Sons.

Message, Kylie \& Andrea Witcomb (red.) 2015. Museum Theory. The International Handbooks of Museum Studies. Chichester: John Wiley \& Sons.

Miller, Riel 2011. Opinion: Futures Literacy Embracing Complexity and Using the Future. Ethos 10, 23-38. https://www.cscollege.gov.sg/ knowledge/ethos/issue\%2010\%20oct\%202011/ pages/Opinion\%20Futures\%20Literacy.aspx.

Museer 2019. Kulturfakta 2020:2. Göteborg: Myndigheten för kulturanalys. https:// kulturanalys.se/wp-content/uploads/2020/09/ museer2019_webb.pdf. Besökt 15 oktober 2020.

Museilag 2017:563. Regeringen. http://rkrattsbaser. gov.se/sfst?bet=2017:563. Besökt 26 oktober 2020 .

Otto, Lene \& Nils Erik Villstrand 2008. Nordiska museets forskarskola. Utvärderingsrapport. Stockholm: Riksbankens Jubileumsfond. http:// www.rj.se/globalassets/rapporter/2008/rj_nmf_ utard.pdf.

Perez Vico, Eugenia 2018. "En översikt av forskningen om samverkansformer och deras effekter.” I Martin Berg, Vaike Fors \& Robert Willim (red.). 
Samverkansformer. Nya vägar för humaniora och samhällsvetenskap. Lund: Studentlitteratur, 29-50. Pyykkönen, Miikka \& Heidi Stavrum. 2018."Enterprising Culture: Discourses on Entrepreneurship in Nordic Cultural Policy." The Journal of Arts Management, Law, and Society 48:2, 108-121.

Rasmussen, Casper Hvenegaard 2019. "Is digitalization the only driver of convergence? Theorizing relations between libraries, archives, and museums." Journal of Documentation, 75(6), 1258-1273.

RAÄ 2019. Uppföljning av hur museilagen tillämpas. Ett regeringsuppdrag. Stockholm: Riksantikvarieämbetet. http://raa.diva-portal. org/smash/get/diva2:1307730/FULLTEXT01.pdf. Besökt 26 oktober 2020.

Rentschler, Ruth 2001. Entrepreneurship: From denial to Discovery in Nonprofit Art Museums? Deakin University, Melbourne, Australia, http://eprints. qut.edu.au/.

Riksutställningar 2017. Guidebok för museer och näringsliv i samverkan. https://issuu.com/ riksutstallningar/docs/guidebok_museer_ naringsliv. Besökt 19 juni 2018.

Rogan, Bjarne \& Arne Brugge Amundsen (red.) 2010. Samling og museum. Kapitler av museenes historie, praksis og ideologi. Oslo: Novus forlag.

Roper, Juliet \& George Cheney 2005. "The meanings of social entrepreneurship today." Corporate Governance International Journal of Business in Society, 5(3), 95-104.

Sacco, Pier Luigi 2016. "Culture 3.0: culture as a platform for creating economic value." In Karin Dalborg \& Mikael Löfgren (red.). The FIKA Project. Perspectives on Cultural Leadership. Nätverkstan Kultur. Latvia: Livonia Print, 44-55.

Salle, Marina La 2014. Appropriation and Commodification of Cultural Heritage. Ethical and IP Issues to Consider. www.sfu.ca/ipinch. Besökt 5 oktober 2020.

Schubert, Karsten 2016. The Curator's Egg. The evolution of the museum concept from the French Revolution to the present day. London: Ridinghouse.

Shane, Scott 2003. A General Theory of Entrepreneurship. The Individual-Opportunity Nexus, Cheltenham, UK and Northampton, MA, USA. Edward Elgar Publishing.

Steyaert, Chris \& Jerome Katz 2004. "Reclaiming the space of entrepreneurship in society: geographical, discursive and social dimensions." Entrepreneurship \& Regional Development 16, 179-196.

Strzelecka, Marianna, Bertram Bynum Boley \& Kyle M. Woosnam 2017. "Place attachment and empowerment. Do residents need to be attached to be empowered?" Annals of Tourism Research $66,61-73$.

Sveriges Museer 2020. Museer under press. Läget i landet enligt 96 museichefer. Sveriges Museer. https://www.sverigesmuseer.se/wp/wp-content/ uploads/2020/02/Museer-under-press_Läget-ilandet-enligt-96-museichefer_2020.pdf. Besökt 20 oktober 2020.

Theobald, Mary Miley 2000. Museum Store Management. Second Edition. Lanham: Altamira Press.

Trost, Jan 2010. Kvalitativa intervjuer. Lund: Studentlitteratur.

von Unge, Elin 2019. "Institutionell oordning. Om glappet I "Museidebatten." Kulturella Perspektiv. 2019(3-4), 24-34.

Wilson, Nick 2010. "Social creativity: re-qualifying the creative economy." International Journal of Cultural Policy. 16(3), 367-381.

Winesmith, Keir \& Suse Anderson (eds.) 2020. The Digital Future of Museums: Conversations and Provocations. Oxon: Routledge.

Zaman, Gheorghe 2015. "Cultural heritage entrepreneurship (CHE) - challenges and difficulties." Procedia - Social and Behavioral Science 188, 3-15.

Zolberg, Vera L. 1986. "Tensions of Mission in 
American Art Museums." I Paul DiMaggio (red).

Nonprofit Enterprise in the Arts: Studies in Mission and Constraint. New York: Oxford University Press, 184-198.

Öhlander, M. 2011. “Analys.” I Lars Kaijser \& Magnus Öhlander (red). Etnologiskt fältarbete. Lund:

Studentlitteratur, 265-296.

Anders Högberg, professor

anders.hogberg@lnu.se

Linnéuniversitetet, Kulturvetenskapliga

institutionen och UNESCO Chair on Heritage Futures samt Centrum för tillämpat kulturarv 39182 Kalmar, Sweden

lnu.se/en/unescochair

Marina Jogmark, fil.dr

marina.jogmark@lnu.se

Linnéuniversitetet, Institutionen för

organisation och entreprenörskap

39182 Kalmar, Sweden 